\title{
Comparing apples and coconuts: Food regimes and (farmers) markets in Brooklyn, USA, and Suva, Fiji
}

\section{FoodDignity}

\author{
Christine M. Porter, ${ }^{a} *$ Lacey Gaechter, ${ }^{\mathrm{b}}$ and Shikha Upadhyaya ${ }^{\mathrm{c}}$ \\ University of Wyoming
}

Submitted September 25, 2019 / Revised November 16 and December 16, 2019 / Accepted December 16, 2019 /

Published online May 7, 2020

Citation: Porter, C. M., Gaechter, L., \& Upadhyaya, S. (2020). Comparing apples and coconuts: Food regimes

and (farmers) markets in Brooklyn, USA, and Suva, Fiji. Journal of Agriculture, Food Systems, and Community

Development, 9(3), 197-214. https://doi.org/10.5304/jafscd.2020.093.020

Copyright (C) 2020 by the Authors. Published by the Lyson Center for Civic Agriculture and Food Systems. Open access under CC-BY license.

\begin{abstract}
Until the advent and spread of supermarkets, the markets that we now call farmers, public, open-air, or traditional markets needed no adjectives. They were simply markets. Currently, the bodies of research about traditional markets common in the Global South and about farmers markets resurging in the Global North tend to be separate. However,

a * Corresponding author: Christine M. Porter, Associate Professor and Wyoming Excellence Chair of Community and Public Health; Food Dignity Principal Investigator; Division of Kinesiology \& Health, College of Health Sciences, University of Wyoming; 1000 East University Avenue, Department 3196; Laramie, WY 82071 USA; christine.porter@,uwyo.edu

b Lacey Gaechter, master's student, University of Wyoming. Gaechter is now a doctoral student in Environmental Health and Engineering, Johns Hopkins Bloomberg School of Public Health; 615 North Wolfe Street; Baltimore, MD 21205 USA.

c Shikha Upadhyaya, PhD student, University of Wyoming. Dr. Upadhyaya is now Assistant Professor and Faculty Fellow for the Public Good, Marketing Department, College of Business and Economics, California State University, Los Angeles; 5151 State University Drive, Simpson Tower 913; Los Angeles, CA 90032 USA.
\end{abstract}

viewed through the lens of food regime frameworks, together these markets come more clearly into focus as globally local alternatives to a corporate regime of supermarkets. As microcases within this macrosociological framework, this paper examines two urban markets — one traditional daily market in Suva, Fiji, and one seasonal Saturday farmers market in East New York, Brooklyn, in the United States. We analyze interviews and surveys with vendors and market-related documents. As we illustrate with brief case descriptions, other than both being urban, the individual markets and their contexts could hardly be more different. One

\section{Funding Disclosure}

Food Dignity (http://www.fooddignity.org) was supported by Agriculture and Food Research Initiative Competitive Grant no. 2011-68004-30074 from the U.S. Department of Agriculture (USDA) National Institute of Food and Agriculture. The United Nations (UN) Entity for Gender Equality and the Empowerment of Women supported the Partners to Improve Markets research. Dr. Susan Dewey of the University of Wyoming was the leading contributor to that research for the UN. A grant from the University of Wyoming's Social Justice Research Center also supported the Suva market research. 
market was formalized early in the colonial food regime, and the other was founded more recently as an alternative to the current neoliberal corporate regime. However, vendors in both reported that selling at the market generates income, autonomy, respect, and social connectedness for them. These commonalities suggest that examining lessons from such markets across communities globally, South or North, traditional or farmers, may offer new insights into how to sustain and expand such markets even in the face of supermarket domination. In addition, doing so with a food regime lens may make that work more useful for informing how to support traditional and farmers market development in ways that help keep aspirations and needs of those who produce, distribute, and consume food at the heart of their work, as real alternatives to neoliberal frameworks.

\section{Keywords}

Farmers Markets, Traditional Markets, East New York Farms, Supermarkets, Food Regimes, Food Sovereignty, Food Dignity, Suva Municipal Market, Partners to Improve Markets, Fiji

\section{Introduction}

The bodies of research literature regarding "traditional markets" that still predominate in most of the Global South and "farmers markets" resurging in the Anglophone North rarely overlap (Cody, 2015a). However, wherever they lie on the compass, such markets enable food producers and preparers to sell their products directly to those who will eat it. ${ }^{1}$ Viewing Southern and Northern markets in a common frame, rather than separately, yields insights into the local and global functions that such markets can and do play. In turn, this knowledge can inform efforts to sustain and grow the contributions of these markets to achieving social goals such as economic and community development, environmental sustainability, food sovereignty, and equity.

This paper begins that project with a historical review of the evolution of markets and with case studies that characterize and compare two urban markets-one in the Global South and one in the Global North. One of the cases is the daily and year-round Suva Municipal Market, located in the capital city of Fiji (a subtropical island nation located in the South Pacific). The other is the East New York Farmers Market, which is held each Saturday in the summer and fall in Brooklyn, New York City, U.S. As we outline here, these two markets seemingly have little in common beyond both being urban markets where eaters can buy food directly from producers and preparers. Thus, any similarities in food system roles found between them may shed light on the roles that urban markets-whether traditional or farmers, in the Global South or North—can and do play in world food regimes. In this paper, we examine both markets at the microcase level to explore what traditional markets of the Global South and farmers markets of the Global North might have in common. In particular we analyze the markets from the standpoint of vendors.

\section{Markets and Food Regimes}

In the late 1980s, Harriet Friedmann and Philip McMichael introduced their food regimes framework (1989), which characterizes global operations of power as manifested in food systems. As McMichael explains in later work, the food regime concept provides a historical lens that is "not about food per se, but about the relations within which food is produced, and through which capitalism is produced and reproduced" (2009b, para. 1). In their 1989 paper, they identified two, sequential regimes. The first was a colonial food regime, which dominated from 1870 until the first World War. This regime is characterized by colonizing nationstates (especially the United Kingdom) feeding their second industrial revolution laborers with calories extracted from territories they had colonized (e.g., India and Fiji). In four of these colonized territories - the U.S., Canada, Australia, and New

\footnotetext{
${ }^{1}$ A "market" in the Global South encompasses what are called farmers or public markets in the Global North. Though these market types differ in some important political and micro-economic ways (see, e.g., Kurland \& Aleci, 2015), we are collapsing them for the macrolevel regime analysis in this paper as a geographic location and economic institution where producers or preparers can sell their products directly to consumers, even if this is not the exclusive or even dominant activity at the market.
} 
Zealand-invaders eventually dominated Indigenous peoples politically and in sheer population numbers. These eventually became "settler" or "new world" states (although the word "settler" obscures the genocidal tactics used by colonizers). Increasingly larger scales of commercial, familygoverned farming began to dominate food production in these settler states. The word "markets" in this period denoted what are now usually specified today as "traditional" markets in the Global South or "farmers" markets in the Global North.

Over the course of two world wars and the waning of formal empires, a new regime emerged by 1947 . In this second regime, commercial farms merged with other forms of industry to form evermore-integrated relations. Friedmann and McMichael characterize this period as the industrial food regime of 1947-1973 (Friedmann, 2005; Friedmann \& McMichael, 1989). This era was marked by the industrialization of production in the green revolution, rapid growth in heavily processed food, and the development project of delivering politically driven food aid to formerly colonized states. This industrial scale of agriculture was designed to feed a nascent global food supply chain, as opposed to peasant and midscale farming used to feed people locally and regionally (McMichael, 2009b). Commodity agriculture emerged in settler and colonizing nations, and a new kind of market - the "super" market—spread as well.

Today, Friedmann, McMichael, and others have increasingly characterized the current, third food regime as the corporate food regime (Burch \& Lawrence, 2009; McMichael, 2005). In this neoliberal third regime, national and multinational agrifood corporations have enrolled state powers, farmers, and financial systems ("financialization") in enabling for-profit, private-sector domination of food systems globally. This includes international investments in agricultural land, otherwise known as land grabs from a food sovereignty perspective (McMichael, 2012). The spread of supermarkets in the Global South and their consolidating supply chain powers everywhere are also key markers and drivers of this corporate regime (Reardon, Timmer, Barrett, \& Berdegué, 2003). As two agri-food supply chain experts note, through a food regimes lens, "supermarkets are among the most powerful transnational corporate forces in the world today and have a significant impact on the lives of increasing numbers of producers and consumers across the globe" (Burch \& Lawrence, 2007, p. 1).

In this food regimes framework, traditional markets in the Global South that still dominate the fresh grocery trade can be seen as hold-outs from earlier regimes, and even from before the colonial regime (e.g., one scholar describes such markets as a "pre-capitalist device" [Hodges, 1988]). In places where traditional markets still dominate, supermarket corporations target them to take over their grocery shares (see, e.g., Economist staff, 2014; Paarlberg, 2013; Trefis Team \& Great Speculations, 2014). In the Global North, where farmers markets are hardly visible in terms of grocery sales, such markets comprise a growing resistance to the corporate food regime and, often, an explicit alternative to the dominant food system (Alkon, 2007; Gillespie, Hilchey, Hinrichs, \& Feenstra, 2007; Kirwan, 2004; Spilková, Fendrychová, \& Syrovátková, 2013).

For those who propose a radically democratic food system as envisioned in the food sovereignty movement, farmers markets and traditional markets can be viewed collectively as alternatives and resistance to a corporate food regime. They could be, and often aspire intentionally to be, part of a food system that "puts the aspirations and needs of those who produce, distribute, and consume food at the heart of food systems and policies rather than the demands of markets and corporations" (Forum for Food Sovereignty, 2007, para. 3). In the context of this macrolevel sociological framework of food regimes and the current corporate regime's "supermarket revolution" (Reardon et al., 2003), we explore, at the micro-case level, what vendor experiences at urban markets of the Global South and Global North have in common.

\section{Methods}

Through the macrolens of food regimes, we compare and contrast cases of two urban markets: a large, daily market in Suva, the capital city of Fiii, and a small Saturday market in the East New York neighborhood of Brooklyn, New York, in the U.S. We start by tracing the trajectory of such markets and supermarkets in each country, then character- 
ize the context and operations of each market, and then focus on the vendors' perspectives on the role of the markets in their lives and communities.

\section{Study Background}

The two market cases presented here are each a small part of two independent and much larger research endeavors. The Suva case derives from a subset of results from the larger United Nations Women's Partners to Improve Markets (PIM) assessment and action project. The East New York market case is a subset of research with the market's organizers and hosts, East New York Farms! (ENYF). ENYF was one of five community partners in a five-year action research project about community food systems called Food Dignity. The first two authors were part of the Food Dignity team. In addition, Porter patronized the Suva and other Fijian markets when living in Fiji for four years in the mid-1990s. Upadhyaya served on the Fiji-based team of the PIM project.

\section{Data Sources}

To outline the history and context for these markets, we reviewed primary sources (e.g., market websites and media coverage), grey literature, and peer-reviewed literature. Three sources of data informed our case study research about the current work of each market: vendor surveys, vendor interviews, and primary documents and reports (see Table 1). Our analysis is also informed by having spent time at these markets as patrons and as researchers.

\section{Surveys}

Vendor surveys have been conducted at each market. In 2013, the PIM project in Fiji included a survey of 101 vendors at the Suva Municipal Market to gather information on what people sell, how much they make, and how much they work at the market. Of these 101, results for the 28 survey respondents who indicated that they grow or prepare at least some of what they sell and reported gross income from the previous weekend's market were analyzed for this paper. (Note that survey participants were not necessarily the same people who participated in interviews.)

In East New York, ENYF staff compile data from vendors about their sales each market day. Results in this paper include analysis of per-vendor and per-market data from the combined 2011 and 2012 seasons from de-identified data that ENYF shared with the authors.

\section{Interviews}

The interviews with vendors at each of the two markets were conducted as part of the larger PIM and ENYF and Food Dignity research projects. For this paper, we reanalyzed them with a focus on vendor perspectives on each market. All interviews were recorded and transcribed.

At the Suva Municipal Market, Upadhyaya

Table 1. Summary of the Three Data Types that Informed Our Case Studies

\begin{tabular}{|c|c|c|}
\hline \multirow[b]{2}{*}{ Data Source } & \multicolumn{2}{|r|}{ Market } \\
\hline & Suva Municipal Market & East New York Farmers Market \\
\hline Vendor surveys & $\begin{array}{l}\text { Survey of } 28 \text { vendors, conducted as part of } \\
\text { the United Nation Women's PIM project }\end{array}$ & $\begin{array}{l}\text { Data compiled by ENYF staff about vendor sales } \\
\text { each market day ( } n=24 \text { vendors in 2011; } n=20 \\
\text { vendors in 2012) }\end{array}$ \\
\hline Vendor interviews & $\begin{array}{l}\text { Interviews of } 40 \text { vendors, also conducted as } \\
\text { part of the PIM project }\end{array}$ & $\begin{array}{l}\text { Interviews of } 4 \text { East New York market vendors, con- } \\
\text { ducted as part of the Food Dignity project }\end{array}$ \\
\hline $\begin{array}{l}\text { Primary documents and } \\
\text { reports }\end{array}$ & $\begin{array}{l}\text { Reports prepared for the PIM project: } \\
\text { - UN Women, } 2009 \\
\text { - PIM, } 2010 \\
\text { - UN Women, } 2011\end{array}$ & $\begin{array}{l}\text { - ENYF website (Daftary-Steel \& Gervais, 2015; } \\
\text { ENYF, n.d., 2016) } \\
\text { - Internal market-related documents from ENYF } \\
\text { - A report by the former director of ENYF for Food } \\
\text { Dignity (Daftary-Steel, 2014) } \\
\text { - The New York State's Division of Minority and } \\
\text { Women's Business Development's survey of one } \\
\text { East New York Farmers Market vendor }\end{array}$ \\
\hline
\end{tabular}


worked as a team with a mentoring colleague to interview 96 vendors over three months in mid-2013. Overall, the busiest market day, Saturday, may have up to 3,500 vendors (see Table 2). As part of the larger PIM project, the researchers' purpose was gathering recommendations from vendors about how to run the market. These interviews, which lasted an average of 25 minutes, were recorded and transcribed. With the emphasis on markets as alternatives or resistance to a corporate food regime in this research, we focused on a subset of vendors who indicated they grew or prepared any portions of the items they sold. In our interview sample, a total of 40 interviewed vendors (out of 96 , or $41 \%$ ) met this criterion. Of these, 38 were Fijian-speaking (iTaukei), and two were Hindi-speaking (IndoFijian). Only one of the vendors interviewed who produced his own food (Fijian-speaking) was male, which reflects the general dominance of women $(87 \%)$ as Fijian market vendors (PIM, 2011).

Interviews with four East New York market vendors were conducted over the past four years as part of the documenting of ENYF work under the case study research of the Food Dignity action research collaboration. Each Saturday market generally has 13-19 vendors, out of the 20 to 24 who regularly sell there over the course of a season. All food vendors at the ENYF market sell at least some food they have prepared or grown themselves. Two of the four interviews are vendors interviewing one other, one was conducted by Porter, and the fourth by another Food Dignity academic partner. Three vendors were women. All four were people of color and residents of the East New York neighborhood. Although we recorded interviews with fewer vendors in East New York than in Suva, the first two authors conducted collaborative case study work with the East New York market's host organization (ENYF), adding to the rigor of our analysis. Additionally, the East New York sample of four out of the more than 20 total seasonal vendors represents a much higher proportion of the target population than our Suva sample (40 out of thousands of vendors).

\section{Primary documents and reports about the markets} and their contexts

Reports and documents about each market and its context formed the third source of data for this research. For the Suva market, this included reports created for PIM, including ones with the involvement of the third author and, especially, her mentor and colleague Susan Dewey (PIM, 2010; UN Women, 2009, 2011). For the East New York Farmers Market, this included information published on the host organization's website (DaftarySteel \& Gervais, 2015; ENYF, n.d., 2016), marketrelated documents that ENYF shared with the authors, and a report by the former director of ENYF for Food Dignity about building a farmers market (Daftary-Steel, 2014). In addition, we examined results from the New York State's Division of Minority and Women's Business Development's interview-style survey of one East New York Farmers Market vendor.

\section{Analysis}

We drew heavily from the survey and document data to characterize each market quantitatively and qualitatively in the brief case studies below. The findings on what the studied markets do for vendors derive from our coding of the transcripts of interviews with vendors who produce or prepare at least part of what they sell (ATLAS.ti GmbH, 2008). Porter and Gaechter open-coded the interview transcripts for benefits and challenges about selling at the market, about growing or making what they sell, and about the relevance of the market overall in their communities. Many of the emergent themes helped to answer the question, "what do markets do," and we conducted a second round of coding focused more narrowly on this question. We then analyzed these coded excerpts from the interview transcripts, yielding the themes outlined in the second results section below.

\section{Limitations}

In addition to the low interview sample size at the East New York market and the small percentage of total vendors interviewed in Suva, as noted above, this study contains other notable limitations. Using our case-study approach to examine similarities and differences between urban markets in two otherwise very different global contexts means our findings are not generalizable. However, situating this work within extensive author experience with these 
markets, related research, and the larger food regimes framework partially ameliorates these issues.

We only investigate the value of the studied markets from the perspective of vendors and do not include any qualitative data from market patrons nor quantitative data such as pricing. Also, our paper specifically examines urban markets and does not compare or contrast the related findings to rural markets, which likely offer unique benefits and challenges to their vendors.

In interviews with East New York market vendors, it was not always possible to determine whether a vendor attributed a given benefit to the market itself or to other aspects of ENYF activities. This is a limitation of our study, but also reflective of Global North farmers markets often being part of an intentional food movement, as resistance to the third regime.

Finally, this research largely aims to locate the role and relevance of markets such as these within food regimes, and specifically within a corporate regime. Thus, it focuses more on aspects of vending that seem most likely to be transferable (though not generalizable), rather than on granular policies and practices about how each market might improve vendor or shopper experiences.

\section{Results}

\section{Markets in Fiji and the U.S.: Traditional, Farmers, and Super}

In the U.S., the word "marketing" used to mean going to market, for both buyers and sellers. The market denoted a destination that, in the Anglophone Global North, is now usually called a "farmers market". The descriptive word "farmers" was not required until the spread of another sort of market, the supermarket. Some scholars identify the first supermarket as the King Kullen store that opened in 1930 in New York City (Burch \&
Lawrence, 2007). Others grant this distinction to a Piggly Wiggly store that opened in 1916 in Memphis, Tennessee. That was the first self-serve grocery store, where shoppers could gather items themselves from shelving rather than providing a list to staff (Marnell, 1971). Either way, by 1960, supermarkets were selling $70 \%$ of groceries in the U.S. (MacFadyen, 1985) and making similar inroads in other settler and European countries.

In the Global South traditional markets remained the primary venue for fresh food trading until at least the 1990s (e.g., Kelly, Seubsman, Banwell, Dixon, \& Sleigh, 2015). In many countries, such as India (Economist staff, 2014; Reardon et al., 2003) and Ghana (Kantar Worldpanel, 2017), they still dominate grocery retail today. Traditional markets are open most or all days of the week. They sell not only locally grown and produced products, but often other goods, including dry groceries and household supplies. They also often serve as storefronts for resellers in addition to enabling people to sell wares they produce or prepare themselves. ${ }^{2}$

In Fiji today, the split of grocery shares between traditional and supermarkets lies in between the extremes of India, where traditional markets dominate, and the U.S., where supermarkets do. Today, for its population of fewer than 850,000 people spread over 100 islands, Fiji has at least 70 supermarket locations representing six corporate chains (Schultz, 2004). At the same time, as one tourist guide accurately observes, "no matter where you go in Fiji, you will see locals with their roadside stalls selling produce. Prices are extremely cheap, and much of the produce is sold in bunches. Every town of any size also has a market, which is a hub for the local community to come and sell their produce" (Fiji Budget Vacations, n.d., "Fruit and vegetables," para. 14). We estimate that Fiji has at

\footnotetext{
${ }^{2}$ The distinction between traditional markets in the Global South and farmers markets in the Global North made in this paper is not a complete one. For example, some of the oldest markets in the U.S. still identify simply as "markets," or as "public markets," and bear some similarities to, for example, the Suva Municipal Market in Fiji. The oldest formal market founded by colonizers of the U.S. began in 1693, established earlier than the nation it now calls home. This is the Reading Terminal Market in Philadelphia, which today is open seven days a week. Baltimore has been home to Lexington Market since 1782 (notably, this market also sold enslaved people), now open six days a week. Boston still has Haymarket, formally founded in 1830 and serving as an informal market location for about a hundred years before that. Today, Haymarket now opens just twice a week, which is similar to how most farmers markets operate in the U.S.
} 
least 21 markets $^{3}$ to their estimated 70 supermarkets, or a ratio of 30 markets for every 100 supermarkets.

A recent study sheds detailed light on food shopping habits and expenditures in Fiji's two largest cities, Suva and Nadi (Johns, Lyon, Stringer, \& Umberger, 2017). Based on a stratified random sample of 1,000 residents in the two cities, the team found that supermarkets take $54 \%$ of the urban food dollar, the main markets garner $28 \%$, roadside stalls $6 \%$, and the fish market $4 \%$. Consumers spend $69 \%$ of their fruit and vegetable dollars at the main markets. These proportions were remarkably consistent across income levels. No consumer good expenditure data is available for shoppers in rural areas and smaller cities and towns in Fiji. Our anecdotal observation suggests that markets, together with roadside stands, may encompass even more of rural grocery market sales of fresh foods.

By contrast, shoppers in the U.S. spend about $9 \%$ of their grocery dollar at "nonstores," a category that lumps sales at farmers market and stands together with mail order and wholesale food purchases (U.S. Department of Agriculture, Economic Research Service, 2014). That said, the number of farmers markets in the U.S. has quadrupled over the past 20 years, far exceeding the growth of supermarket locations. In 1994, the U.S. had seven farmers markets for every 100 supermarkets $(1,755$ vs. 24,600). By 2014 the ratio was 22 to 100, with 8,268 farmers markets (Low et al., 2015) and 37,716 supermarkets (Statista, 2014).

\section{Introducing Each Market}

Suva Municipal Market in Suva, Fiji

Suva is Fiji's capital city, home to about 85,000 people. The country overall is home to 837,271 people, over half of whom are native Fijian, or iTaukei, and about a third of whom are Indo-Fijian (i.e., of Indian descent) (Fiji Bureau of Statistics, n.d.). The Indo-Fijian population is a legacy of Britain's colonization of the islands in 1874. The British rulers brought indentured laborers from colonized India to work on Fijian sugar cane plantations. Fiji regained independence in 1970.

The Suva Municipal Market was established in 1891 during colonial rule. It was originally named the Queen Victoria Jubilee Memorial Native Market to formalize the street trading of produce in Suva. The market has been in its current location as Suva Municipal Market since 1950. It is Fiji's largest market.

The market is open six days a week, Monday to Saturday, starting at $6 \mathrm{am}$. Shoppers can fulfill nearly all of their grocery needs there, and produce prices are generally lower than at supermarkets. A popular travel guide for tourists calls this market "the beating heart of Suva" (Lonely Planet, n.d., para. 1). Suva City Council, which manages the markets, says, "it is not only Suva's major food supplier and a means of livelihood for thousands of people, but is also a celebration-a six-day fair" (Suva City Council, n.d., para. 1).

Most of the market's vendors are hosted inside a hexagonal, two-story building and a neighboring rectangular produce hall. It is next to the busy bus station and steps away from the Suva Wharf. The market accommodates about 2,400 vendors, with up to 3,500 on the busiest days, including people selling from sidewalks and stalls outside (Dewey, 2011; Suva City Council, n.d.). The city employs a market master who oversees two supervisors and eight attendants to run the market. A cleaning crew comes on Sundays, which is the only day the market is closed.

Vendors selling upstairs in the hexagonal building offer mostly dry products such as spices, onions, garlic, and kava root (yaqona), which is used in indigenous Fijian ceremonies as well as recreationally. Traders on the market's ground floor, in

\footnotetext{
${ }^{3}$ Based on available PIM reports, web searches, and our personal experience, Fiji markets include (with location if not indicated by the market name): Bailey Bridge (Nasinu), Flagstaff (Suva), Labasa, Lautoka, Nabowalu (Bua), Nadi, Nausori, Ratu Dovi Roadside (Nasinu), Sigatoka, Southpoint (Nakasi), Suva, Vaileka (Raki Raki), Tavua, Savusavu, Korovu, Ba, Seaqaqa, Nabouwalu, Navua, Korolevu, and Levuka. Of these, at least 13 are municipal markets (PIM, 2011). This excludes informal sales that many producers and gatherers make directly to consumers via roadside stalls, sidewalk offerings, and individual solicitation (e.g., door-to-door and rural women flagging down buses travelling long-distance routes, which stop to allow passengers to purchase palm-frond baskets full of foraged fruits in season).
} 
the produce hall, and outside sell an enormous variety of fresh vegetables and fruit, both local and imported, along with some prepared foods catering to the needs of an ethnolinguistically diverse population. There is also a neighboring fish market, which is managed separately and not included in this study. Many vendors travel long distances over rough roads or by boat from outer islands to sell their own and their communities' produce at the market (Dewey, 2011). As noted above, the Suva market supplies nearly $70 \%$ of the fruits and vegetables that Suva city residents buy, in dollar value (Johns et al., 2017). Among market vendors who were surveyed in this study (see Table 2), their gross intakes on a Friday and Saturday market day averaged just over US\$50 a day. Amounts ranged from US $\$ 9$ to US $\$ 250$ per day. (For reference, Fiji's minimum wage is currently FJ $\$ 2.68$ /hour, or US\$1.22. The U.S. minimum wage at the time of this research is US $\$ 7.25$ /hour.)

\section{East New York Farmers Market}

East New York is a neighborhood in the borough of Brooklyn, in New York City, New York, U.S. This area was also colonized by Europeans, but centuries earlier than Fiji was, first by the Dutch and later by the British. Today, the neighborhood's population is roughly double that of Suva's. The neighborhood is about half African American or Afro-Caribbean and about 40\% Latinx. First-generation immigrants compose one-third of the population (NYCStat Stimulus Tracker, 2015).

\section{Table 2. Descriptive Summary of Two Community Contexts and Their Markets}

\begin{tabular}{|c|c|c|}
\hline Characteristic & Suva, Fiji & East New York, Brooklyn, U.S. \\
\hline Community Population & 85,000 residents & 174,000 residents \\
\hline Dominant Community Demographics & $\begin{array}{l}\text { 56\% iTaukei (native Fijian) } \\
37 \% \text { Indo-Fijian }\end{array}$ & $\begin{array}{l}50 \% \text { Black } \\
40 \% \text { Hispanic } \\
33 \% 1^{\text {st }} \text { generation immigrants }\end{array}$ \\
\hline Management & $\begin{array}{l}\text { Local government: Suva City Council. } \\
\text { The market generates net revenue for } \\
\text { the city. }\end{array}$ & $\begin{array}{l}\text { Community-based organization: ENYF. } \\
\text { Revenue covers } \sim 23 \% \text { of operational } \\
\text { costs (Daftary-Steel, } 2014 \text { ). }\end{array}$ \\
\hline Market Days & Monday-Saturday, all year & $\begin{array}{l}\text { Saturdays for } 21-23 \text { weeks in season, } \\
\text { plus a Wednesday produce stand }\end{array}$ \\
\hline $\begin{array}{l}\text { Average vendor revenue on a Saturday, } \\
\text { in US } \$ \text { b (and revenue range). }\end{array}$ & $\begin{array}{l}\$ 51 \\
\text { (range: } \$ 9-\$ 250)\end{array}$ & $\begin{array}{l}\$ 381 \\
\text { (range: } \$ 24-\$ 2,891)\end{array}$ \\
\hline Total market sales, annual, in US\$b & $\sim \$ 8,340,000$ in 2009 & $\$ 118,049$ (average 2009-2013) \\
\hline Vendor fee per day, per table, in US\$b & $\begin{array}{l}\sim \$ 1.50 \text { (table and shelter provided if } \\
\text { indoors; many rent more than one ta- } \\
\text { ble) }\end{array}$ & $\begin{array}{l}\$ 6-\$ 18 \text { (plus } \$ 2-\$ 10 \text { optional table } \\
\text { and tent rental) }\end{array}$ \\
\hline Number of vendors, Saturdays & $2,400-3,500$ & About 24 \\
\hline Number of customers, Saturday average & Unknown & About 1,500 \\
\hline Year founded & $\begin{array}{l}\text { Formalized by colonizers in } 1891 \text { (in } \\
\text { current location since 1950) }\end{array}$ & 1998 \\
\hline Venue & $\begin{array}{l}\sim 6,690 \mathrm{~m}^{2} \text { in a two-story building and } \\
\text { a produce shed,c plus outdoors }\end{array}$ & $\begin{array}{l}\text { Open-air on a temporarily closed block } \\
\text { of a city street }\end{array}$ \\
\hline
\end{tabular}

a Fiji data from 2013 survey results from 28 vendors who indicated they sell food they produced or prepared and reported earnings for previous Friday and Saturday combined, divided here by two to provide a one-day estimate. East New York data from combined 2011 and 2012 individual vendor reports gathered by ENYF at each market. This calculation counts gardeners as one vendor, excludes data for three vendors who sold only on one market day in a season, and adjusts for actual days each vendor sold at the market (out of 21 possible market days each season in those years).

${ }^{b}$ Calculated with an exchange rate of US $\$ 1=2$ Fiji dollars

${ }^{c}$ Author calculations based on estimates from satellite images. For reference, the median supermarket area in the U.S. is about $4,300 \mathrm{~m}^{2}$ (Food Marketing Institute, n.d.). 
The East New York Farmers Market was founded in 1998 by a neighborhood not-for-profit organization, the ENYF project of United Community Centers, in collaboration with residents in the neighborhood. During neighborhood community meetings in the mid-1990s, East New York residents articulated the need for better retail access to food and better opportunities for youth. The ENYF project was founded in response, including a farmers market that drew on local assets of more than 65 community gardens.

The market operates every Saturday in season, from June to November, and is open from 9 am to $3 \mathrm{pm}$. ENYF also operates a farm stall on Wednesday afternoons.

The founding goals of the East New York Farmers Market were threefold. One was to provide residents who otherwise do not have easy access to fresh and affordable or culturally relevant foods, with convenient access to these items. They began with the Saturday market and later expanded to offer a Wednesday farm stand. These limited hours cannot compare to the 24-hour convenience of some retail stores. The market does not meet all the dietary needs of its community. (In response to this comment, ENYF notes its efforts to expand its offerings, including soliciting vendors to sell baked goods and vegan items. It also notes that "our market is the only place in East New York to find local and organic produce and Caribbean specialty crops like karela, bora, and callaloo" [United Community Centers, n.d., para. 2]). Another goal is to offer a safe community space, which led ENYF to beautify the area where it hosts the farmers market and to integrate performing arts and family activities into sales days. The final goal was to engage local youth. Through paid internships, teenagers from East New York run their own Youth Farm, set up market stands for local vendors, help gardeners who may need harvest assistance, and sell their farm and local gardeners' produce at a community "Share Table" at both the Saturday market and the Wednesday farm stand.

To keep the market financially accessible, ENYF substantially subsidizes it. ENYF estimates that market revenues cover under a quarter of its operating costs. Former ENYF director Sarita Daftary-Steel notes that "we think of our market as a program—not just a market" (2014).

ENYF employs a market manager and mentors youth interns to run the market with associated activities and programs. Saturday market vendors include 10 to 16 local community members who sell food and crafts they grow or make and a few (one to three) regional farmers. In addition, about 50 local gardeners sell some of their harvest at a "Share Table" staffed by ENYF youth interns. They also sell produce from the Youth Farm grown by the interns. Counting the gardeners as one vendor, the market includes about 24 total vendors over the course of a season.

About half the purchases made at the East New York Farmers Market each year (e.g., 49\% in each of 2011 and 2012) are made with nutrition benefit funds supplied to families struggling with low incomes via state and federal programs. Vendors gross an average of about US $\$ 380$ at a Saturday market, with a range of US $\$ 24$ to over US $\$ 2,800$. Table 1 summarizes the characteristics of the markets and their contexts.

\section{What the Markets 'Do," from Vendor Perspectives} Vendors in both markets identified four main benefits of their participation: generating income, providing autonomy, garnering respect, and increasing social connectedness. Unless otherwise specified, these results derive from the analysis of the interview transcripts with 44 vendors who make or prepare at least part of what they sell at the Suva or East New York markets.

\section{Generate income}

Income was the primary reason that Suva market vendors cited for both participating in and enjoying their market work. For example, one vendor noted that, "It's just about how to support the family, money-wise. It's just all about money-wise." Another said, "I'm happy because we get money." For most of the Suva vendors in this study, even those only selling on weekends, working in the market is what enables their participation in the monetized component of the nation's economy. For example, as one vendor notes, "At the village, we plant dalo, cassava, everything like that; only the salt, the sugar, the kerosene we used to buy, only that. That's why I want to come and sell the good." 
Another says, "We get money incoming, sometimes I help the family, the whole family for the food, the electricity, the water." Paying for children's education was also frequently mentioned as a reason for needing to make money in the market; most schools in Fiji charge fees, and families must also provide school uniforms. One vendor said that before she started selling in the market, "We either got the bread or paid the fees." A grandmother vending explained, "That's why I'm selling. For the school fees, the uniform, the shoes, everything like that for the schooling. Books." A vendor's daughter, who earned a degree at the University of the South Pacific, said, "I thank my parents for their support. Without this market, I wouldn't be anything now."

In East New York, the full market is only on Saturdays and only for about half the year. Vending there is not a way for families to make a living. However, one of the vendors described the extra income earned at the market as helping "to make ends meet." Three discussed using the market as a way to get started as entrepreneurs in order to make a living; for example, one said, "I don't know where I would be a few years from now... but hopefully I might bring it into a business."

As mentioned above, the survey results help quantify the revenue benefits of the markets for vendors, though only as gross rather than net takings, and with enormous ranges (see Table 2). As mentioned above, the 28 Suva vendors who responded to the 2013 survey and indicated they sell at least some food they grew or prepared themselves, reported approximately US $\$ 50$ each day at the previous weekend's market (Friday and Saturday). Annualized, if selling for 48 weekends each year, this would total US $\$ 4,800$ a year.

In East New York, the average takings for a vendor selling at a Saturday market in the 2011 and 2012 seasons were just over US\$380. The average total revenue per vendor was just under US $\$ 5,600$ over the course of the season. Vendors attended an average of 11 markets out of the 21 possible in each of those years. Including only East New York community vendors (i.e., excluding regional farmers), the average Saturday market revenue was US $\$ 227$. The average season total for these hyperlocal vendors was US $\$ 2,307$, who sold at an aver- age of just under 10 markets each season. Regional farmers, who grow food outside New York City, sold at an average of 14 markets in each of the 2011 and 2012 seasons, and each garnered an average of US $\$ 18,033$ in total revenue over the course of the season.

\section{Foster autonomy}

Both East New York and Suva traders mentioned enjoying having control of their own businesses, time, and decisions. The benefits of being one's own boss emerged as an especially strong subtheme of autonomy in Fiji. For example, one Fijian vendor explained, "Before, I used to work in government ... but I quit all that just to be my boss and be in the market, and I don't want to listen to anybody and to let anybody to be my boss, so I just want me to be my own boss, so that's why I prefer to come to the market." Another said, "Other jobs, somebody else own us. In the market, only yourself own yourself." One Fijian woman summarized the advantage of being a vendor as "nobody boss you, only the God boss you". Another described it as "empowering women." East New York vendors spoke about autonomy as a benefit of entrepreneurship. One said he jumped at the opportunity to join the farmers market when he saw an advertisement for vendors because he had "always wanted to be an entrepreneur." Another vendor said she started her market business because she wanted to control her work schedule and does not like a "9 to 5" timetable.

\section{Garner respect}

Fijian participants especially discussed earning respect from their work in the market, usually as a direct result of their ability to earn money. For example, when one woman was asked if her family is proud of her, she answered, "They proud, because when I go back, I take the money back so that my family can live on that." Another discussed this gain for a friend, who also vends at the Suva market, saying her friend's family members "really support her, they really support. They're really proud of her, that she's getting money, supporting the family." In a way unattached to revenue, but related to the larger social justice mission of ENYF, an East New York vendor mentioned the respect 
he gained from his son, saying “yeah, he's proud of his dad you know, in terms of he sees his dad as doing something that he enjoys and that he loves."

However, in exceptions to this theme, two female Suva vendors spoke about their market participation inspiring pity. For example, one woman, speaking through a translator, said, "that her family feel sorry for her coming to the market, sitting down and then selling, spending time in the market. She said it's her duty to come and support the family. But for them, it's only men that brings money to the family."

\section{Create social connections}

Enjoying social aspects of the market was another benefit that vendors in both markets reported. One woman in Suva explained, "I like to stay in the market. For selling, for meeting the friend." Another offered, "I don't know, but myself I say, better I don't stay home. Come to the market, do something, talk to somebody, make you feel little better. If you stay home, you feel bad, eh llaughing]." Another reported, "I feel good when I stay in the market. I met a lot of friends, we can love each other, we know each other. Some people we didn't know, they came to the market, we all know."

The ENYF vendors also mentioned enjoying socializing at the market, saying, for example, "I enjoy the little parties we have here." Some also focused on the benefits of cultural exchange. One vendor noted that the market "brings all the people from all walks of life, you know, so it's a good thing. Everybody get together, you know, socialize." In East New York, vendors talked about connectedness in ways entwined with the other programs and activities that ENYF does, as mentioned in the next results section. A cultural theme also appeared in Suva. For example, one Suva market vendor explained, "I like what I'm doing selling, meeting people, selling to everybody, different kind of people, different culture." Another said it had pushed her to be more socially and culturally open, saying, "Yes! Good change. The way we should talk, we should respect each other, to go and talk to other people we don't know. We should go and give sometimes to our friends to come and share the table."

\section{Food and other themes}

The four themes above were the dominant ones that vendors in both Suva and East New York shared about what markets do for them. An additional theme for Suva vendors, not shared by the Brooklyn ones, was logistical and financial challenges of selling at the market. For example, many Fijian vendors travel from distant rural areas and sleep at the market. Many also supplement their own wares with produce bought from wholesalers and resellers, which vendors noted bring smaller margins.

An additional theme for the Brooklyn vendors was the relationship of the market with other activities of the market host organization, ENYF, including festivals, loan programs, and community gardening. These themes were integrated with those about their experiences as vendors at the market. For example, within the span of a few minutes, one vendor spoke of participating in a pepper festival, being the first to sell West Indian long beans at the market, serving as a community food educator, beekeeping, and deciding to grow and sell her own corn.

Although all the vendors who contributed to this study, in both Suva and Brooklyn, grow or prepare and sell food, food in the context of consumption was only a minor theme. For Suva vendors, the dominant connection was via income, with many noting they use the market revenues to buy the food they cannot produce themselves (tea, salt, sugar, and flour being the most mentioned) for their families. Suva vendors did not often mention eating what they grow, although frequent comments about buying only staples with their market income imply that subsistence farming and gardening are major sources of food. For example, one vendor noted that "In town, you have to pay everything. In the village, no, only the sugar." One East New York vendor also mentioned that growing so much food not only makes money at the market, but also saves money on groceries, noting that her family goes "to the grocery store for codfish and maybe some juice, so we don't really buy a whole lot of stuff. Like our tomatoes, we freeze our tomatoes." Enough gardeners have harvests beyond their household needs that they help stock the East New York Farmers Market 
Share Table, described above.

Food quality was a minor theme for vendors in both places. One Suva vendor noted her produce was "fresh, healthy, straight from the farm," in contrast to those who bought from wholesalers (most who compared these sources focused on the better profit margin, rather than on produce quality). Another vendor in Fiji said, "We have to just bring the good produce so that the customer can, because they also work for their money. They spend good money, too, so that we have to sell good produce." East New York market vendors also viewed the homegrown produce more favorably than produce available at supermarkets; for example, one compared her corn to that from a store saying, "by the time we get it, it's already starting to lose its flavor." In addition, one vendor in each place mentioned the quality advantage of knowing the food they grow is not contaminated with chemicals.

A final food theme unique to East New York vendors was their role in providing access to quality produce (e.g., "My supermarket was horrible. Food was old, the produce section was small") and to culturally important produce (e.g., "We were one of the first farmers that had the long beans") that is usually not available in neighborhood stores.

\section{Discussion}

Harriet Friedmann has said that she searches for "daisies in the concrete" of an industrialized, globalized food system (personal communication, 2009). Friedmann's flower analogy conjures an inorganic versus biological metaphor for corporate vs. alternative food supply chains. In one metaphor, heavy-gauge steel carries, for example, Kenyan green beans to London supermarkets and Fiji Water to Brooklyn bodegas. In the rare instances when these inorganic chains or cogs break, we mine and forge materials for their repair. The alternative is more like a daisy chain-short, organic, easily broken, and easily regenerated — as long as flowers grow. If comparing these two markets to Friedmann's flowers, one has survived the concrete pouring, and another has broken through it. These two markets are old vs. new, Global South vs. Global North, daily vs. weekly, all year vs. 23 weeks in a season, large vs. small, and with munici- pal vs. not-for-profit management. One is a traditional market "hold-out" from the global spread of supermarkets and one a farmers market founded much more recently as an alternative to the corporate food regime. However, in spite of their many differences, we find similarities in what they do for vendors and, more abstractly, in their socio-political roles when viewed through a food regime framework lens, as discussed below.

The four main kinds of benefits reported by vendors in both Suva and Brooklyn are generating income, autonomy, respect, and social connectedness. These social and economic benefits also mirror those identified in previous research conducted with markets in the Global North, such as in a study with farmers selling in upstate New York (Griffin \& Frongillo, 2003), and the Global South, such as in Chiapas, Mexico, and Lima, Peru (Bellante, 2017; Cody, 2015b). As noted, not all participating vendors in Suva reported that the market garnered them respect. Some women vendors said that they, instead, receive pity for having to help their husbands support their families. Some Fijian vendors interviewed (but none of those in Brooklyn) also discussed the challenges associated with traveling to the market and the small profit margins they gained when they had to first buy food from wholesalers.

The income benefits that vendors generally reported qualitatively in interviews are also quantified by the survey results. Though these revenue figures are gross, not net, comparing them to income figures helps put the relative amounts into perspective. For example, the weekend gross revenue reported by Suva vendors in the 2013 survey annualizes to an amount nearly identical to Fijis average annual per capita income that year (World Bank, n.d.). In East New York, the full market is only open on Saturdays during just over half the year, so vending there is not a way for families to make a living. However, the income generated is not insubstantial. The average gross annual revenue for the Saturday vendors who are from the East New York community (US\$2,307) represents about 7\% of the median household income in East New York (New York City Department of Housing Preservation, 2015). The average gross earnings for each of the regional farmers selling at the East 
New York market were nearly eight times that.

Also, both markets provide their urban communities with access to fresh, regional, and culturally important foods-whether fresh coconuts arriving from Koro Island in Fiji, leafy green callaloo grown in Brooklyn, or apples from orchards outside New York City. Both markets examined here also serve their communities at large, with higher quality foods and foods not available at all in supermarkets. This contrasts with findings from some other studies that report customers being disproportionately wealthier than the communities in which the markets are located, particularly in the Global North (Alkon, 2008; Brown, 2002; Rice, 2015; Schupp, 2016). Some markets, such as those discussed here, are exceptions to this, serving the communities in which they are based (e.g., Hicks \& Lambert-Pennington, 2014).

The primary limitation of the ENYF market's service to the community might be its limited availability, with just one market and one farm stand day per week in season. This means it cannot offer primary jobs for vendors and is not as accessible as grocery stores in terms of open hours. In a comprehensive study of the Suva Municipal Market, Dewey (2011) identifies major challenges that the market's predominately female vendors experience. These vendors report difficult and unsanitary conditions both in the transit they must take to and from rural villages to the city and at the combined open-air, outdoor market, which does not provide adequate running water or toilets. Female vendors do also face some stigma (or "pity," to use some vendors' words), and potentially other consequences of undermining the Fijian norm that positions only men as income generators for a family (Dewey, 2011).

Turning to the question of the role traditional and farmers markets play in food regimes, some scholars question how much of an alternative they really provide to the neoliberal engine of the corporate regime (Alkon \& Mares 2012; Guthman, 2008; McClintock, 2014). These and other markets aim to advance human well-being in part "by liber- ating individual entrepreneurial freedoms and skills," per Harvey's definition of neoliberalism (2005). Our results suggest that the markets in East New York and Suva are succeeding in that neoliberal goal.

The markets are organized to also achieve many other social goods, including via fostering entrepreneurship for non-neoliberal ends, for a "moral economy," for example (Leiper \& ClarkeSather, 2017, p. 840). They distribute economic opportunities rather than consolidate them, enabling vendors to directly exchange what they produce, rather than relying on bottlenecked, centralized corporate markets (see, e.g., Griffin \& Frongillo, 2003). In East New York, the host organization heavily subsidizes the market as a program that provides public social and celebration space, community-led workshops, and affordable and appropriate food in addition to economic opportunities for community members as vendors (Daftary-Steel, 2014; Daftary-Steel \& Gervais, 2015; Daftary-Steel, Porter, Gervais, Marshall, \& Vigil, 2017). Since the time of our data gathering, the Suva market organizers have partnered with the United Nationssponsored "Markets for Change" program to train vendors, especially women vendors, to strengthen their "economic security, rights and livelihoods" (UNDP Pacific Office in Fiji, 2016).

Also, the immediate institutional contexts of local government or not-for-profit organizations that host these markets are characterized by much more than the neoliberal framework of "private property rights, free markets, and free trade" (Harvey, 2005) that shapes the third regime. These market operations are not subsumed by the "financialization" of supermarket chains in the corporate food regime (Burch \& Lawrence, 2013). They are possibly even immune to it; traditional markets and farmers markets are not targets for takeover by incorporation but by reduction or elimination (including by imitation ${ }^{4}$ ). And, as the financial earnings figures in both Suva and Brooklyn show, the markets have provided significant opportunities for highly distributed and autonomous in-

\footnotetext{
${ }^{4}$ See, e.g., China's Sun-Mart mimicking open-air market displays (Trefis Team \& Great Speculations, 2014) and, at the product level, Prego "Farmers' Market" tomato sauces that the manufacturer describes as "made with ingredients you would find at your local farmers market" (Campbell Soup Company, 2016, para. 1).
} 
come generation to people who are producing and preparing food in each community and region at micro- and small scales. As a study of markets in Argentina suggests, farmers markets are often both complicit in and yet a means to resist neoliberalism (Leslie, 2017), and this is the case with these two markets as well.

Viewed through the historical and socio-political lens of food regimes, these markets-in East New York, Suva, and around the world-are globally local. As discussed by Alkon (2008), many farmers markets operations and activities have moral drivers, with income generation being employed as one means to social ends in a "morally embedded economic exchange" (p. 488). Returning to the Nyéléni food sovereignty declaration (Forum for Food Sovereignty, 2007), these public, traditional, and farmers markets can put the aspirations and needs of those who produce, distribute, and consume food at the heart of their work, and often do. They offer perhaps the most promising fresh food grocery alternative to a reign of supermarkets (and to the more recent growth in online grocery markets [Kantar Worldpanel, 2017]). Even in the U.S., although farmers markets and stands garner a very small share of the grocery dollar (less than $9 \%$ vs. at least $38 \%$ in Fiji), the availability of markets in communities is relatively high. The ratio of farmers markets to supermarkets in the U.S. is $73 \%$ of Fiji's ratio (22 vs. 30 markets per 100 supermarkets).

This macro perspective on the regime role that traditional and farmers markets play around the world raises questions about how to best sustain and expand the community and farmer benefits of local markets while minimizing their challenges and limitations. We suggest that examining market and other "alternative" food system questions through a global lens, encompassing both South and North as done with two cases here, may offer new insights into what markets can do for small and regional farmers and food-insecure communities, especially in terms of resisting industrialized, neoliberal food systems that do not serve them.

In the case of markets, a persistent question in both North and South are what market policies and practices are most effective at centering people—as producers, vendors, and eaters—as benefi- ciaries, and how to maximize market production of social benefits. These are questions raised in the PIM study in Fiji and by community-based organizations partnering in the Food Dignity collaboration (in direct response, a former director of ENYF wrote a market guide [Daftary-Steel, 2014]). This kind of global analysis at local scales could be useful in better understanding and supporting other alternative food actions, such as food hubs. For example, Fiji has been supporting the development of "collection centres" in Fiji, to replace imported produce used in the tourist industry with yields from local farmers (Tuqa, Lobendahn, \& Bainivalu, 2018). Their efforts seem to face at least some challenges similar to those of U.S.-based food hubs, such as a lack of postharvest infrastructure that preserves produce quality, the high cost of transportation, and the inadequate proportion of revenue that goes back to farmers who otherwise sell directly at markets (Hoey, Shapiro, \& Bielaczyc, 2018).

\section{Conclusion}

This study adds to the literature in several ways. One, it makes a relatively minor addition to research on markets by collecting and synthesizing some detailed empirical data in two case studies. These data may offer useful comparisons in future studies that characterize, for example, reported vendor earnings and other benefits.

Two, it compares and contrasts two very different urban markets—one large, daily, Global South market that is over 120 years old, and one small, seasonal and weekly, Global North neighborhood market less than 20 years old. We find that both foster income generation, autonomy, and social connectedness while distributing means of food exchange and making fresh and culturally relevant foods available to their communities.

These are interesting, but also not groundbreaking findings. However, they contribute in a third way. They begin to break ground on examining specific instances of alternative food initiatives across the Global South and North, which is currently uncommon in academic research. This may be the first study to do so with markets (although a recent study usefully compared markets in U.S. and Austrian cities to elucidate their embedded values 
[Klimek, Bingen, \& Freyer, 2018]). Given the commonalities in benefits to vendors in two otherwise radically different markets and contexts, useful answers to future research and action questions outlined above may be found by examining local alternative food initiatives through a lens that spans the Global North and South.

Finally, the regime framework offers a power- ful global and historical lens for understanding, and possibly predicting or even shaping, food system shifts. However, it can be unwieldy when used to examine specific instances of resistance and alternatives to the current corporate regime. We suggest that global comparisons such as this one can help stabilize, inform, and focus the regime framework lens on such local, empirical cases.

\section{References}

Alkon, A. H. (2007). Growing resistance: Food, culture and the Mo' Better Foods Farmers' Market. Gastronomica: The Journal for Food Studies, 7(3), 93-99. https://doi.org/10.1525/gfc.2007.7.3.93

Alkon, A. H. (2008). From value to values: Sustainable consumption at farmers markets. Agriculture and Human Values, 25(4), 487-498. https://doi.org/10.1007/s10460-008-9136-y

Alkon, A. H., \& Mares, T. M. (2012). Food sovereignty in US food movements: Radical visions and neoliberal constraints. Agriculture and Human V alues, 29(3), 347-359. https://doi.org/10.1007/s10460-012-9356-z

ATLAS.ti GmbH. (2008). ATLAS.ti: Qualitative data analysis (Version 5.6.3). Berlin. Retrieved from http://www.atlasti.com/

Bellante, L. (2017). Building the local food movement in Chiapas, Mexico: Rationales, benefits, and limitations. Agriculture and Human V alues, 34(1), 119-134. https://doi.org/10.1007/s10460-016-9700-9

Brown, A. (2002). Farmers' market research 1940-2000: An inventory and review. American Journal of Alternative Agriculture, 17(4), 167-176. https://www.cambridge.org/core/journals/american-journal-of-alternative-agriculture

Burch, D., \& Lawrence, G. (2007). Understanding supermarkets and agri-food supply chains. In D. Burch \& G. Lawrence (Eds.), Supermarkets and agri-food supply chains: Transformations in the production and consumption of foods (pp. 126). Cheltenham, UK: Edward Elgar Publishing.

Burch, D., \& Lawrence, G. (2009). Towards a third food regime: Behind the transformation. Agriculture and Human V alues, 26(4), 267-279. https://doi.org/10.1007/s10460-009-9219-4

Burch, D., \& Lawrence, G. (2013). Financialization in agri-food supply chains: Private equity and the transformation of the retail sector. Agriculture and Human V alues, 30(2), 247-258. https://doi.org/10.1007/s10460-012-9413-7

Campbell Soup Company. (2016). Prego introduces new farmers' market Italian sauce varieties [Press release]. Retrieved from https://www.campbellsoupcompany.com/newsroom/press-releases/prego-introduces-new-farmers-market-italiansauce-varieties/

Cody, K. (2015a). The internationalization of alternative food networks: Farmers' markets, community gardens, and agricultural exchange (Doctoral dissertation). University of California, Santa Cruz. Retrieved from https://escholarship.org/uc/item/7dz9g2sp

Cody, K. (2015b). "La misma realidad de cada lugar es diferente" ("The same reality of each place is different"): A case study of an organic farmers market in Lima, Peru. Journal of Agriculture, Food Systems, and Community Development, 5(2), 53-69. https://doi.org/10.5304/jafscd.2015.052.011

Daftary-Steel, S. (2014). Building a great farmers market. Retrieved from https://tinyurl.com/yccamfaf

Daftary-Steel, S., \& Gervais, S. (Producer). (2015). ENYF retrospective case study [Prezi presentation]. Retrieved from https://prezi.com/kixjpppdqbqz/enyf-retrospective-case-study/

Daftary-Steel, S., Porter, C.M., Gervais, S., Marshall, D. \& Vigil D. (2017). What grows in East New York: A case study of East New York Farms! an examination of expectations of urban agriculture. In C. Bosso \& R.L. Sandler (Ed.), Feeding Cities: Improving Local Food Access, Security, and Sovereignty (pp. 95-112). New York: Earthscan/Routledge.

Dewey, S. (2011). Markets and women's market trading in the Pacific Islands: An overview of social contexts and ongoing challenges. Asian Women, 27(3), 1-23.

East New York Farms! (ENYF). (2016). East New York Farmers' Market, 2015 fact sheet. Retrieved from https://drive.google.com/file/d/0B65IVsA81sX2R2Nva0NPMkdKZkE/view 
ENYF. (n.d.). Selling at the market 101. Retrieved in 2016 from https://drive.google.com/file/d/0B65IVsA81sX2ZGNqU0JIVEQ0ZkE/view

Economist, The. (2014, October 2014). Grocery retailing in India: A long way from the supermarket. The Economist. Retrieved from https://www.economist.com/business/2014/10/18/a-long-way-from-the-supermarket

Fiji Budget Vacations. (n.d.). Cost of Living in Fiji 2013 - 2014. Retrieved March 16, 2015, from http://www.fiji-budget-vacations.com/prices-of-fiji-food-and-cost-of-living.html

Fiji Bureau of Statistics. (n.d.). 2012 data in Fiji statistics at a glance. Retrieved from http://www.statsfiji.gov.fj/

Food Industry Association. (n.d.). 2015 data in Our researcb: Supermarket facts. Retrieved from https://www.fmi.org/our-research/supermarket-facts

Forum for Food Sovereignty. (2007). Nyéléni 2007- Final declaration. Retrieved from http://www.nyeleni.org/spip.php?article280

Friedmann, H. (2005). From colonialism to green capitalism: Social movements and emergence of food regimes. In F. H. Buttel \& P. McMichael (Eds.), Research in rural sociology and development (Vol. 11, pp. 227-264): Emerald Group Publishing.

Friedmann, H., \& McMichael, P. (1989). Agriculture and the state system: The rise and decline of national agricultures, 1870 to the present. Sociologia Ruralis, 29(2), 93-117. https://doi.org/10.1111/j.1467-9523.1989.tb00360.x

Gillespie, G., Hilchey, D. L., Hinrichs, C. C., \& Feenstra, G. (2007). Farmers' markets as keystones in rebuilding local and regional food systems. In C. C. Hinrichs \& T. A. Lyson (Eds.), Remaking the North American food system: Strategies for sustainability. (pp. 65-83). Lincoln: University of Nebraska Press.

Griffin, M. R., \& Frongillo, E. A. (2003). Experiences and perspectives of farmers from Upstate New York farmers' markets. Agriculture and Human V alues, 20(2), 189-203. https://doi.org/10.1023/a:1024065526440

Guthman, J. (2008). Neoliberalism and the making of food politics in California. Geoforum, 39(3), 1171-1183. http://dx.doi.org/10.1016/i.geoforum.2006.09.002

Harvey, D. (2005). A brief history of neoliberalism. Oxford, UK: Oxford University Press.

Hicks, K., \& Lambert-Pennington, K. (2014). Evaluating the South Memphis Farmers Market as a strategy to improve access to healthy foods: Lessons from 2011. Journal of Agriculture, Food Systems, and Community Development, 4(2), 45-59. https://doi.org/10.5304/jafscd.2014.042.014

Hodges, R. (1988). Primitive and peasant markets. Oxford, UK: Basil Blackwell.

Hoey, L., Shapiro, L. F., \& Bielaczyc, N. (2018). "Put your own mask on before helping someone else": The capacity of food hubs to build equitable food access. Journal of Agriculture, Food Systems, and Community Development, 8(3), 41-60. https://doi.org/10.5304/jafscd.2018.083.012

Johns, C., Lyon, P., Stringer, R., \& Umberger, W. (2017). Changing urban consumer behaviour and the role of different retail outlets in the food industry of Fiji. Asia-Pacific Development Journal, 24(1), 117-145. https://doi.org/10.18356/88463870-en

Kantar Worldpanel. (2017). Winning omnichannel: Hyper and supermarkets lose market share globally. Retrieved from: https://www.kantarworldpanel.com/global/News/Hyper-and-supermarkets-lose-market-share-globally

Kelly, M., Seubsman, S.-a., Banwell, C., Dixon, J., \& Sleigh, A. (2015). Traditional, modern or mixed? Perspectives on social, economic, and health impacts of evolving food retail in Thailand. Agriculture and Human Values, 32(3), 445 460. https://doi.org/10.1007/s10460-014-9561-z

Kirwan, J. (2004). Alternative strategies in the UK agro-food system: Interrogating the alterity of farmers' markets. Sociologia Ruralis, 44(4), 395-415. https://doi.org/10.1111/j.1467-9523.2004.00283.x

Klimek, M., Bingen, J., \& Freyer, B. (2018). Metropolitan farmers markets in Minneapolis and Vienna: A values-based comparison. Agriculture and Human Values, 35(1), 83-97. https://doi.org/10.1007/s10460-017-9800-1

Kurland, N. B., \& Aleci, L. S. (2015). From civic institution to community place: The meaning of the public market in modern America. Agriculture and Human Values, 32(3), 505-521. https://doi.org/10.1007/s10460-014-9579-2

Leiper, C., \& Clarke-Sather, A. (2017). Co-creating an alternative: The moral economy of participating in farmers' markets. Local Environment, 22(7), 840-858. https://doi.org/10.1080/13549839.2017.1296822 
Journal of Agriculture, Food Systems, and Community Development

ISSN: 2152-0801 online

https://www.foodsystemsjournal.org

Leslie, I. S. (2017). Improving farmers markets and challenging neoliberalism in Argentina. Agriculture and Human Values, 34(3), 729-742. https://doi.org/10.1007/s10460-017-9774-z

Lonely Planet. (n.d.). Suva Municipal Market. Retrieved April 28, 2020, from https://www.lonelyplanet.com/fiji/viti-levu/suva/attractions/suva-municipal-market/a/poi-sig/441102/362606

Low, S. A., Adalja, A., Beaulieu, E., Key, N., Martinez, S., Melton, A., . . Jablonski, B. B. R. (2015). Trends in U.S. local and regional food systems: A report to Congress (Publication No. AP-068). U.S. Department of Agriculture, Economic Research Service. Retrieved from https://www.ers.usda.gov/publications/pub-details/?pubid=42807

MacFadyen, J. T. (1985). The rise of the supermarket. American Heritage, 36(6), 23-32.

Marnell, W. H. (1971). Once upon a store: A biography of the world's first supermarket. New York: Herder and Herder.

McClintock, N. (2014). Radical, reformist, and garden-variety neoliberal: Coming to terms with urban agriculture's contradictions. Local Environment, 19(2), 147-171. https://doi.org/10.1080/13549839.2012.752797

McMichael, P. (2005). Global development and the corporate food regime. In F. H. Buttel \& P. McMichael (Eds.), New directions in the sociology of global development (Vol. 11, pp. 265-299). West Yorkshire, UK: Emerald Group Publishing.

McMichael, P. (2009a). A food regime genealogy. Journal of Peasant Studies, 36(1), 139-169. https://doi.org/10.1080/03066150902820354

McMichael, P. (2009b). A food regime analysis of the 'world food crisis.' Agriculture and Human Values, 26(4), $281-295$. https://doi.org/10.1007/s10460-009-9218-5

McMichael, P. (2012). The land grab and corporate food regime restructuring. The Journal of Peasant Studies, 39(3-4), 681701. https://doi.org/10.1080/03066150.2012.661369

New York City Department of Housing Preservation. (2015). East New York Neighborhood Snapshot. Retrieved from https://www1.nyc.gov/assets/hpd/downloads/pdf/community/East-New-York-Snapshot.pdf [no longer online]

NYCStat Stimulus Tracker. (2015). Spotlight on East New York. http://www.nyc.gov/html/ops/nycstim/downloads/pdf/east new york spotlight 110831.pdf

Paarlberg, R. (2013). Food politics: What everyone needs to know (2nd ed.). New York: Oxford University Press.

Partners to Improve Markets (PIM). (2010). Economic analysis report on four markets: Suva, Nausori, Sigatoka, Labasa (report). UN Women. Retrieved from https://www.empowerwomen.org/en/resources/documents/2014/11/economicanalysis-report-on-four-markets-suva-nausori-sigatoka-labasa

Reardon, T., Timmer, C. P., Barrett, C. B., \& Berdegué, J. (2003). The rise of supermarkets in Africa, Asia, and Latin America. American Journal of Agricultural Economics, 85(5), 1140-1146. https://doi.org/10.1111/j.0092-5853.2003.00520.x

Rice, J. S. (2015). Privilege and exclusion at the farmers market: Findings from a survey of shoppers. Agriculture and Human Values, 32(1), 21-29. https://doi.org/10.1007/s10460-014-9513-7

Schultz, J. T. (2004). Globalization, urbanization and nutrition transition in a developing island country: A case study in Fiji. In FAO (Ed.), Globalization of food systems in developing countries: Impact on food security and nutrition (pp. 195-214). Retrieved from http://www.fao.org/3/y5736e/y5736e00.htm

Schupp, J. L. (2016). Just where does local food live? Assessing farmers' markets in the United States. Agriculture and Human V alues, 33(4), 827-841. https://doi.org/10.1007/s10460-015-9667-y

Spilková, J., Fendrychová, L., \& Syrovátková, M. (2013). Farmers' markets in Prague: A new challenge within the urban shoppingscape. Agriculture and Human Values, 30(2), 179-191. https://doi.org/10.1007/s10460-012-9395-5

Statista. (2014). Number of supermarket stores in the United States in 2013 and 2014, by format. Retrieved from http://www.statista.com/statistics/240892/number-of-us-supermarket-stores-by-format/

Suva City Council. (n.d.). Suva's Municipal Market. Retrieved April 28, 2020, from http://suvacity.org/municipal-market/

Trefis Team \& Great Speculations. (2014, April 2). Challenges Wal-Mart faces in Mexico and China. Forbes. Retrieved from https://www.forbes.com/sites/greatspeculations/2014/04/02/challenges-wal-mart-faces-in-mexico-andchina/\#515f460d17d4

Tuqa, A., Lobendahn, K., \& Bainivalu, S. (2018). Farm-to-table via collection centres in Fiji. In Technical Centre for Agricultural and Rural Cooperation (CTA) (Ed.), Experience capitalization: Resilience and productivity in the Pacific (pp. 5861). Wageningen, Netherlands: CTA. https://hdl.handle.net/10568/98980 
United Community Centers. (n.d.). Farmers' market. Retrieved April 28, 2020, from https://ucceny.org/farmers-market/

United Nations Development Programme (UNDP) Pacific Office in Fiji. (2016, December 5). Rural women secure their livelihoods through financial literacy training. Retrieved from

http://www.pacific.undp.org/content/pacific/en/home/presscenter/articles/2016/12/05/rural-women-securetheir-livelihoods-through-financial-literacy-training.html

UN Women. (2009). Fiji markets profiles (report). Suva, Fiji: UN Entity for Gender Equity and the Empowerment of Women (UN Women). Retrieved from https://asiapacific.unwomen.org/en/digital-library/publications/2009/8/fiji-markets-profiles

UN Women. (2011). Summary survey results from nine markets in Fiji. Suva, Fiji: UN Women. Retrieved from https://asiapacific.unwomen.org/en/digital-library/publications/2011/8/survey-results-from-nine-markets-in-fiji

U.S. Department of Agriculture, Economic Research Service. (2014). Table 2_Food at home: Total expenditures. Retrieved from: http://www.ers.usda.gov/data-products/food-expenditures.aspx

World Bank. (n.d.). GNI per capita, Atlas method (current US\$): Fiji. Retrieved in 2017 from https://data.worldbank.org/indicator/ny.gnp.pcap.cd 